\title{
Touraine-Soulente-Golé Syndrome: A Rare Case Report and Review of the Literature
}

\author{
Sumir Kumar, Sandeep Sidhu, Bharat Bhushan Mahajan \\ Department of Dermatology, G.G.S Medical College and Hospital, Faridkot, India
}

Touraine-Soulente-Golé Syndrome (TSG) or pachydermoperiostosis is a rare disorder characterized by pachydermia, periostosis \& digital clubbing. Herein, we report a case of a 27 year old male, with the looks of a 47 year old. He presented with excessive wrinkling on his face since past 8 years. TSG syndrome was suspected and examined by histopathological, endocrinological and radiological studies for the confirmation of clinical diagnosis. (Ann Dermatol 25(3) $352 \sim 355,2013$ )

\section{-Keywords-}

Hypertrophic osteoarthropathy, Pachydermoperiostosis, Touraine-soulente-golé syndrome

\section{INTRODUCTION}

Touraine-Soulente-Golé (TSG) Syndrome or primary hypertrophic osteoarthropathy (PHO) is a genodermatosis characterized by digital clubbing of hands and feet, enlargement of extremities, secondary to bones and periarticular tissue proliferation. There is bilateral ptosis, leonine facies, and skin thickening along with joint pains. It is $\mathrm{PHO}$ of a presumable autosomal dominant inheritance with mainly variable expression and incomplete penetrance. Although recessive autosomal inheritance and

Received February 14, 2011, Revised September 1, 2011, Accepted for publication September 5, 2011

Corresponding author: Sumir Kumar, Department Of Dermatology, G.G.S Medical College, Faridkot 151203, India. Tel: 91-98887-07940, E-mail: doc9220@gmail.com

This is an Open Access article distributed under the terms of the Creative Commons Attribution Non-Commercial License (http:// creativecommons.org/licenses/by-nc/3.0) which permits unrestricted non-commercial use, distribution, and reproduction in any medium, provided the original work is properly cited. $\mathrm{x}$-linked mutations may also be present, these may differ in severity and prevalence of clinical features ${ }^{1}$. Secondary form of diseases can occur in association with other diseases like Pulmonary: Bronchogenic carcinoma, nasopharyngeal carcinoma, bronchiectasis, abscess, emphysema, metastasis, mesothelioma, cystic fibrosis; Cardiac: Congenital heart disease, aortic or axillary artery graft rejection and gastrointestinal tract: Crohn's disease, ulcerative colitis, polyps, biliary atresia, biliary cirrhosis, biliary neoplasm and esophageal carcinoma ${ }^{2}$.

\section{CASE REPORT}

A 27-year-old male came with complaints of repetitive wrinkling and thickening of skin on face and scalp along with broadening of hands since 8 years ago. He also complained of increased oiliness on the face. This healthy Indian male with normal physique and intelligence level was the 1st son of non-consanguineous parents, his elder brother was 31 . He has a 3 years old son and a 5 years old

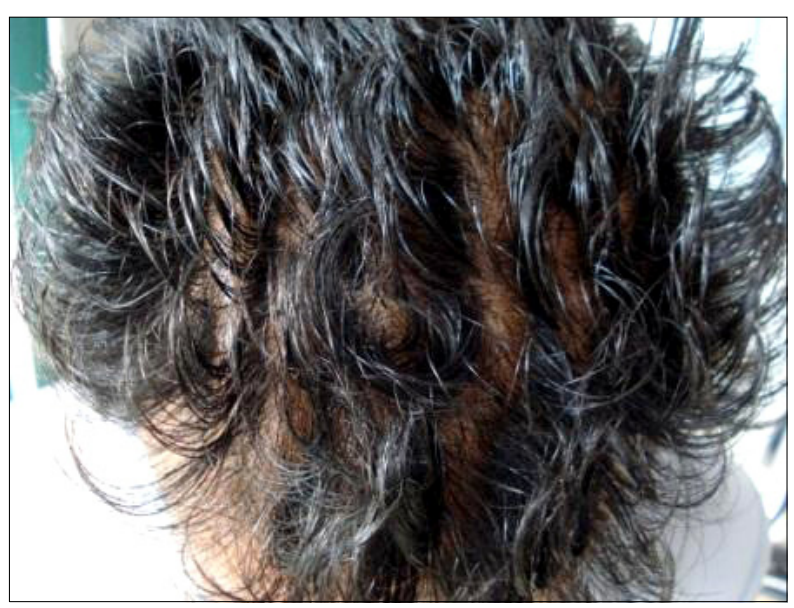

Fig. 1. Cutis verticis gyrata. 
daughter. Family history was unremarkable. History of joint pains, oral and genital ulceration, hoarseness of voice, epistaxis and sensory loss was denied. No similar history was found in the family. Physical examinations revealed scalp skin was folded, giving appearance of peculiarity cutis verticis gyrata (Fig. 1), whereas the hair growth appeared normal. Eyebrows appeared dense. Skin over face was thickened, non-pinchable, greasy to touch and folded, giving appearance of leonine faces (Fig. 2). Follicular openings were prominent and so were the video-dermoscopy. In addition, clubbing of fingers and toes was presented along with broadening of hands and fingers (Fig. 3). Cutaneous examination over the rest of his

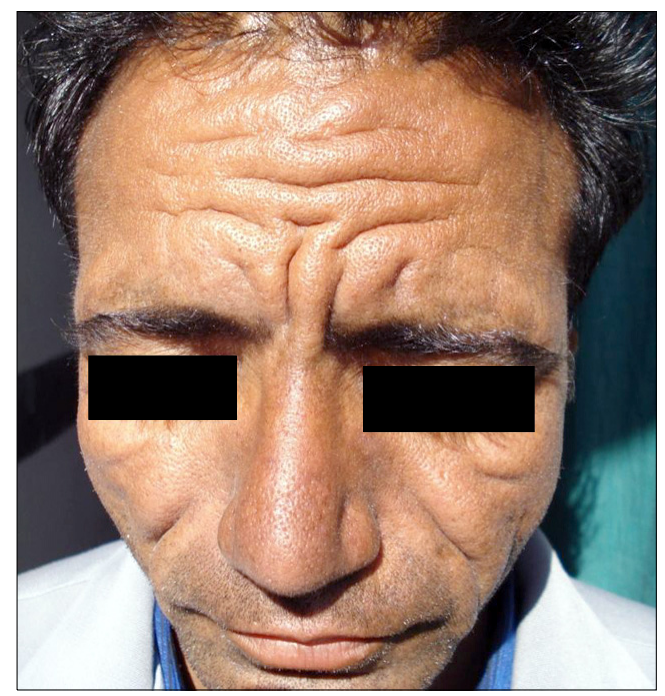

Fig. 2. Leonine faces.

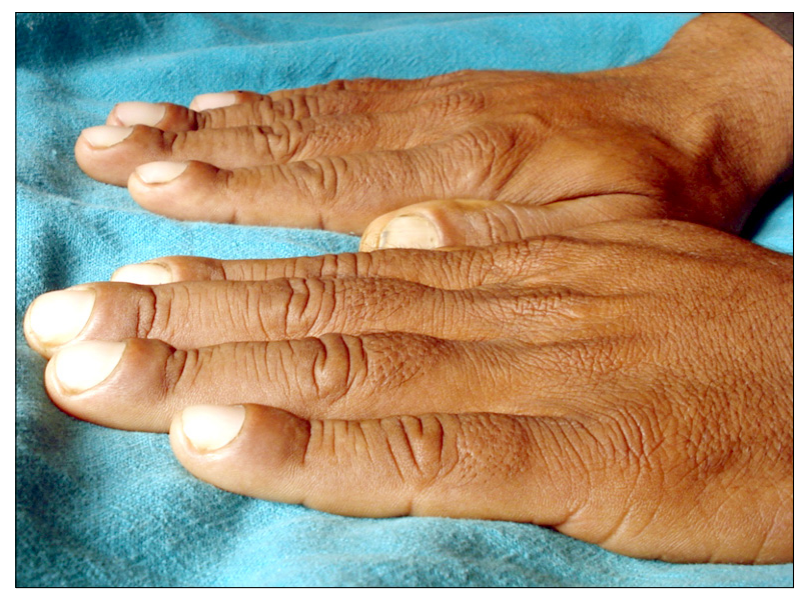

Fig. 3. Broadening of hands and fingers. body including mucosae was normal. Laboratory investigations included growth hormone assay, thyroid profile, and Venereal Diseases Research Laboratory Assay and were found to be within normal limits. Erythrocyte sedimentation rate was elevated (45 $\mathrm{mm}$ in $1 \mathrm{st}$ hour). Serum calcium, alkaline phosphatase and other biochemical tests were also within normal limits. Smears for lepra bacilli were negative. Radiological investigations included radiographs' of skull, which were normal including sella turcica. Long bones of legs showed minimal periosteal reaction along the shaft (Fig. 4) and his feet showed evidence of cortical erosions and tufting ends of terminal phalanges. Histopathological examination from skin be-

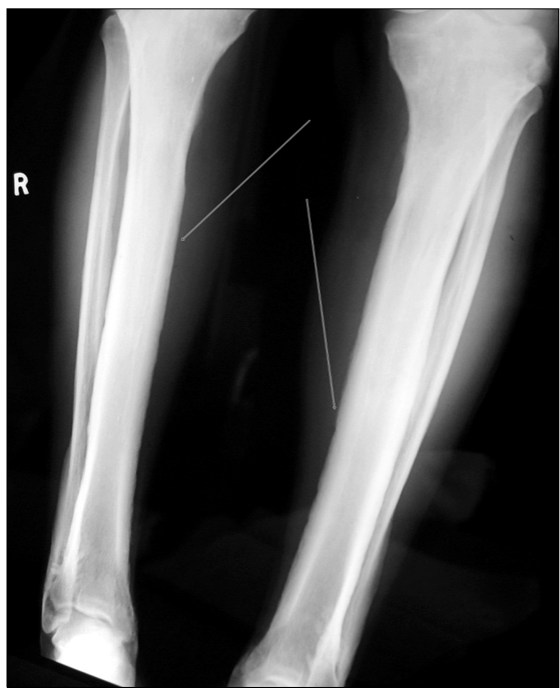

Fig. 4. Periosteal reaction along the shaft.

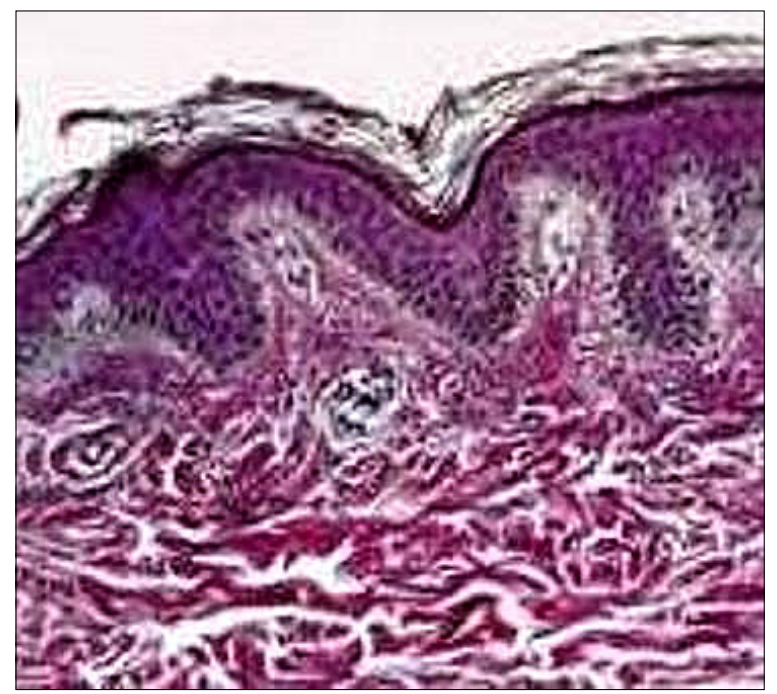

Fig. 5. Histopathological examination showing hyperplasia epidermal and dermal changes $(\mathrm{H} \& \mathrm{E}, \times 10)$. 
hind ear lobule showed a hyperplastic epidermis and dermis (Fig. 5). On the basis of history, clinical features, radiological and lab findings, the diagnosis of TSG syndrome was formulated.

\section{DISCUSSION}

TSG syndrome, which is a rare disease, precise incidence of which is not known, with approximately estimated prevalence $0.16 \%{ }^{3}$. TSG syndrome accounts for $3 \sim 5 \%$ of all cases of hypertrophic osteoarthropathy and occurs predominantly in men $(80 \%)$, in which severe phenotype is observed ${ }^{4}$. Pathogenesis is not fully clear. Biopsy of skin and bone marrow may show an exacerbated proliferation of fibroblasts, which are associated with diffused epidermal hyperplasia and lymphohistiocytic infiltration with collagen redistribution. Studies have shown a circulating connective tissue growth modulator, increase in plasmatic substances including osteocalcin, endothelin-1, $\beta$-tromboglobulin, PDGF, v W factor, VEGF and dermal acid mucopolysaccharide of ground substance ${ }^{5,6}$. Increased steroid receptors concentration in these patients suggest an increase in tissue sensitivity to circulating sex hormones ${ }^{7}$. One study showed TSG syndrome mapped to band 4q33-q34 and mutation in HPGD, encoding 15-hydroxyprostaglandin dehydrogenase, the main enzyme of prostaglandin degradation ${ }^{8}$. The clinical condition typically begins in adolescence and manifest variably depending on the presentations. Touraine et al. ${ }^{9}$ described 3 forms of syndrome: Complete (pachydermia and periostitis), Incomplete (with periostitis and no pachydermia), and Forme fruste (pachydermia with minimal or absent periostitis). Characteristic cutaneous changes are pachydermia i.e. thickening of facial skins resulting in leonine faces, over scalp, cutis verticis gyrata, and over the eyes blephroptosis $^{10}$. These changes give a characteristic known as 'bull dog appearance'. Other influences are acne, eczema, seborrhea, palmoplanter hyperhydrosis, burning sensation of hands and feet, clubbing of fingers with or without paronychial thickening. Skeletal and radiological changes are symmetrical and irregular subperiosteal deposits in metaphysis and epiphysis of long bones especially in the forearm and leg, and small bones, widening ends of long bones especially wrist and knee, enlargement of distal part of digits with resorption of phalanges and acro-osteolysis, calcification of ligaments and interosseous membranes, cortical thickening with or without narrowing of medullary cavity, enlargement of paranasal sinuses ${ }^{4,11-13}$. There is joint effusion, inflammation and reduction of joint spaces, contractures in late stages and rarely periarticular erosion ${ }^{14}$. In axial skeleton, changes are spondylolithiasis, with narrowing of intervertebral disc spaces and foramina, ligamentous ossification and laxity ${ }^{4}$. Differential diagnoses are secondary hypertrophic osteoarthropathy, thyroid acropachy, acromegaly, van Buchem's disease, diaphyseal dysplasia and syphilitic periostitis. There is no specific treatment for the condition. Surgical management includes plastic surgery and correction of associated bony deformities $^{15-17}$. Medical treatment includes non-steroidal anti-inflammatory drugs (NSAIDs), corticosteroids, tricyclic antidepressants, resedronate, and pamidronate and tamoxifen citrate to control arthritis. Due to heterogeneity in transmission of TSG and difficulty of genetic tests, guidance to these patients is often complicated ${ }^{13}$. Such disease runs insidiously and chronically for about a decade with phases of exacerbations and asymptomatic periods stabilizing spontaneously ${ }^{13}$. Disabilities may be left-sided kyphosis, restricted motions and neurological complications which may occur later. However, it usually doesn't interfere with patient's life expectancy ${ }^{18}$.

Current clinical and radiological findings favor the 3rd type diagnosis, the forme fruste of TSG syndrome in our case. Other family members were also advised for clinico-radiological examinations. Patient was referred to plastic surgery department for the improvement of cosmetic appearance. As the condition is amenable to treatment, prognosis depends mostly upon the extent of joint involvements and periarticular periosteal thickening. Detailed investigation and early diagnosis may help in prevention of disabilities later in life.

\section{REFERENCES}

1. Castori M, Sinibaldi L, Mingarelli R, Lachman RS, Rimoin DL, Dallapiccola B. Pachydermoperiostosis: an update. Clin Genet 2005; 68:477-486.

2. Lowenthal MN, Tombak A, Lowenthal A. Secondary hypertrophic osteoarthropathy ( $\mathrm{HOA})$ mimicking primary $\mathrm{HOA}$ (pachydermoperiostitis or Touraine-Solente-Golé) syndrome. Isr Med Assoc J 2004;6:64.

3. Jajic I, Jajic Z. Prevalence of primary hypertrophic osteoarthropathy in selected population. Clin Ex Rheum 1992;10:73.

4. Resnick D. Enostosis, hyperostosis, and periostitis: In: Resnick D, Kransdorf MJ, editors. Bone and joint imaging. 3rd ed. Philadelphia, PA: Elsevier Saunders, 2005:14331435.

5. Oikarinen A, Palatsi R, Kylmäniemi M, Keski-Oja J, Risteli J, Kallioinen M. Pachydermoperiostosis: analysis of the connective tissue abnormality in one family. J Am Acad Dermatol 1994;31:947-953.

6. Silveira LH, Martínez-Lavín M, Pineda C, Fonseca MC, Navarro C, Nava A. Vascular endothelial growth factor and hypertrophic osteoarthropathy. Clin Exp Rheumatol 2000; 18:57-62. 
7. Bianchi L, Lubrano C, Carrozzo AM, Iraci S, Tomassoli M, Spera G, et al. Pachydermoperiostosis: study of epidermal growth factor and steroid receptors. Br J Dermatol 1995;132: 128-133.

8. Uppal S, Diggle CP, Carr IM, Fishwick CW, Ahmed M, Ibrahim $\mathrm{GH}$, et al. Mutations in 15-hydroxyprostaglandin dehydrogenase cause primary hypertrophic osteoarthropathy. Nat Genet 2008;40:789-793.

9. Touraine A, Solente G, Gole L. Un syndrome osteodermopathique: la pachydermie plicaturee avec pachyperiostose ds extremites. Presse Med 1935;43:1820-1824.

10. Alves AP, Holanda Filha JG, Jerônimo FT. Eyelid ptosis associated with pachydermoperiostosis: case report. Arq Bras Oftalmol 2005;68:401-404.

11. Cooper RG, Freemont AJ, Riley M, Holt PJ, Anderson DC, Jayson MI. Bone abnormalities and severe arthritis in pachydermoperiostosis. Ann Rheum Dis 1992;51:416-419.

12. Hedayati H, Barmada R, Skosey JL. Acrolysis in pachydermoperiostosis. Primary or idiopathic hypertrophic osteoarthropathy. Arch Intern Med 1980;140:1087-1088.
13. Jajic Z, Jajic I, Nemcic T. Primary hypertrophic osteoarthropathy: clinical, radiologic, and scintigraphic characteristics. Arch Med Res 2001;32:136-142.

14. Schumacher HR Jr. Hypertrophic osteoarthropathy: rheumato logic manifestations. Clin Exp Rheumatol 1992;10 Suppl 7:35-40.

15. Seyhan T, Ozerdem OR, Aliagaoglu C. Severe complete pachydermoperiostosis (Touraine-Solente-Golé syndrome). Dermatol Surg 2005;31:1465-1467.

16. George L, Sachithanandam K, Gupta A, Pulimood S. Frontal rhytidectomy as surgical treatment for pachydermoperiostosis: a case report. J Dermatolog Treat 2008;19:61-63.

17. Brüner S, Frerichs $\mathrm{O}$, Raute-Kreinsen $U$, Fansa $H$. Correction of finger clubbing in primary hypertrophic osteoarthropathy (Touraine-Solente-Gole syndrome). Handchir Mikrochir Plast Chir 2007;39:135-138.

18. Goyal S, Schwartz AR, Richards GM, Goyal R. Pachydermoperiostosis [Internet]. New York (NY): Medscape; [updated on 2008 Apr 30]. Available from: http://www. emedicine.com. 